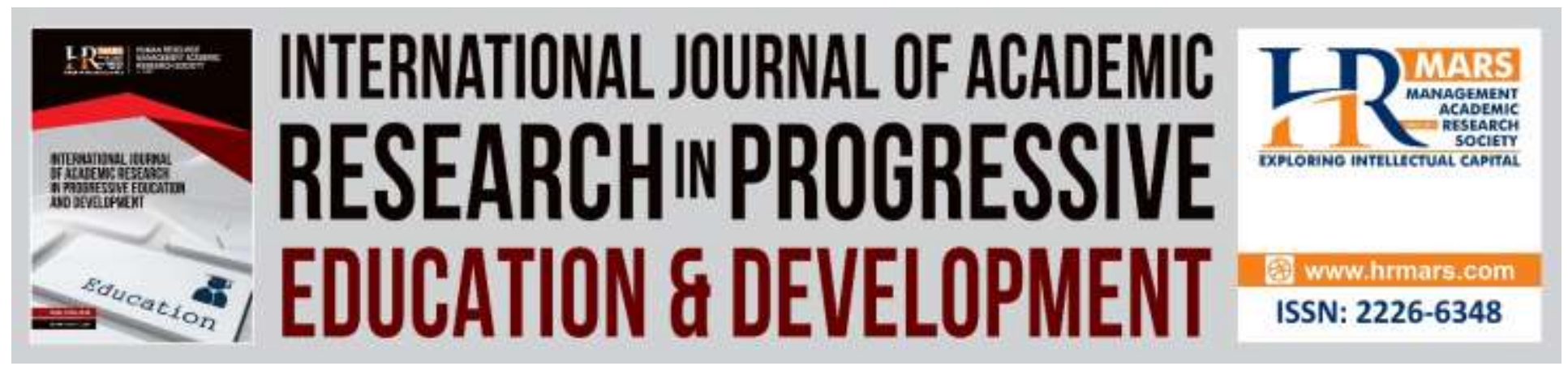

\title{
Gender Digital Divide: Digital Skills among Malaysian Secondary School
}

\author{
Nur 'Atikah Ahmad, Ahmad Fauzi Mohd Ayub \& Mas Nida Khambari
}

To Link this Article: http://dx.doi.org/10.6007/IJARPED/v8-i4/6692

DOI:10.6007/IJARPED/v8-i4/6692

Received: 10 October 2019, Revised: 24 October 2019, Accepted: 10 November 2019

Published Online: 29 November 2019

In-Text Citation: (Ahmad, Ayub, \& Khambari, 2019)

To Cite this Article: Ahmad, N. A., Ayub, A. F. M., \& Khambari, M. N. (2019). Gender Digital Divide: Digital Skills among Malaysian Secondary School. International Journal of Academic Research in Progressive Education and Development, 8(4), 668-687.

Copyright: (C) 2019 The Author(s)

Published by Human Resource Management Academic Research Society (www.hrmars.com)

This article is published under the Creative Commons Attribution (CC BY 4.0) license. Anyone may reproduce, distribute, translate and create derivative works of this article (for both commercial and non-commercial purposes), subject to full attribution to the original publication and authors. The full terms of this license may be seen at: $\underline{\text { http://creativecommons.org/licences/by/4.0/legalcode }}$

Vol. 8(4) 2019, Pg. 668 - 687

http://hrmars.com/index.php/pages/detail/IJARPED

JOURNAL HOMEPAGE

Full Terms \& Conditions of access and use can be found at http://hrmars.com/index.php/pages/detail/publication-ethics 


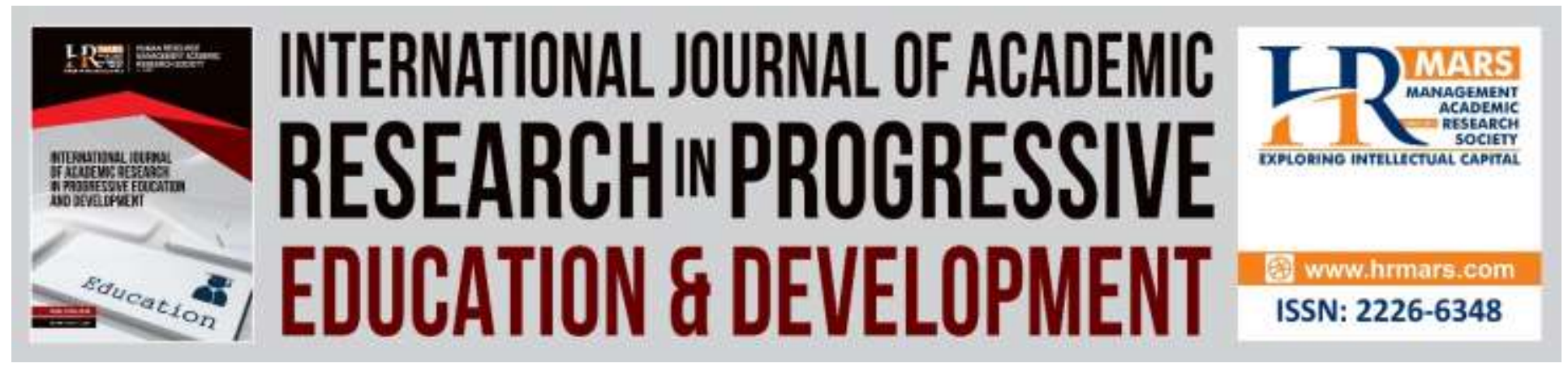

\title{
Gender Digital Divide: Digital Skills among Malaysian Secondary School
}

\section{Nur 'Atikah Ahmad, Ahmad Fauzi Mohd Ayub* \& Mas Nida Khambari}

Faculty of Educational Studies, Universiti Putra Malaysia (UPM), 43300 Serdang, Selangor MALAYSIA

\begin{abstract}
The Digital Divide is an important issue with serious consequences, individuals affected, society as well as threatens economy and productivity growth of a country. It was believed no longer exists in this 21st century era, amongst adolescents due to internet and smart devices penetration increment in Malaysia. Thus, survey conducted among 292 national secondary students from Hulu Langat district, chosen by using proportional random sampling to seek the possibility of digital divide existence by mean of digital skills between genders. There is no divide exist in digital devices ownership especially smartphones and home internet access. However, there was gender divide in digital skills in all dimensions except for information navigation skills even when gender is controlled. Male students had higher digital skills compared to female, whereby female only higher in information navigation skills. There was gender divide exist as well among urban secondary students, whereby urban male had highly digital skilled in computer operational, internet operational, social and creative skills, whilst urban female digitally skilled in information navigation. However, rural female suffered more in digital divide, whereby they were behind in digital skills level compared to rural male in the three dimensions. These findings indicate more efforts should be taken by the policy makers and authorities in enhancing students' digital skills as well as bridging the digital divide in accommodating them well into today's informative world.
\end{abstract}

Keywords: Digital Skills, Digital Divide, Secondary Education, Gender

\section{Introduction}

In this era of 21st century, the rapidness of technology is well projected and has been world-shaking criterion for the growth and development for all countries in today's informative world. Information and Communication Technology (ICT) or Internet services have become a need in everyday life and considered as tool for economy and social improvement of a country. Technological development has widened the opportunity of internet access and usage, whereby the cost of having any technological devices with build-in internet access has come down to the 
affordable point, where most Malaysian would have the access (DeWitt \& Siraj, 2010; Wong, Khong, \& Chu, 2012). It can be seen clearly that most young generation were likely having access the digital devices with internet technology installed such as smart phones, laptops as well as handy technologies, such as iPads, iPods or tablets (Plowman, Stevenson, Stephen, \& McPake, 2012). These wide accesses has made the young generations more technology-ready, sensitive to new technological trends, and adopt better to new technology (Kate, 2015; Kopaiboon, Reungtrakul, \& Wongwanich, 2014). These multi-hand-held devices and the digital technologies are so well integrated in today's everyday life and changed the lifestyle, where by fantasy future in the back then had becoming a reality.

In spite of all these advantages offered by the ICT, it also proven creating new inequalities and diversity among school students, society or countries, which individuals or social groups that couldn't keep-up the advancement of new communication technologies are increasing (Carvalho, Bessa, Oliveira, Guedes, Peres \& Magalhaes, 2012). This inequality is known as "digital divide". The term digital divide is generally described as the gaps or discrepancies in accessing ICT, where by the gap contributed to the material inequalities, social and education inequality between individuals or countries (Van Dijk, 2012). The divides usually occurs among genders, geographical areas and socio-economic groups, which due to not have IT background, lack of ICT accession and ownership, lack of time and experience for using ICT, lack of creativity requirements, lack of critical thinking as well as lack of English language proficiency (Ghobadi \& Ghobadi, 2015; Yaman, 2015).

The digital online world has truly shaped all kind of today tasks whereby most of private and government sector affairs are highly depending on it, as well as the education sector compared to the life in few years back. The world has becoming more automation, bigger data pool and mostly has gone cloud online-based activities, either to provide wider range of education opportunities access, efficiently managing learning and teaching, or saving resources. It proven by the growing educational technologies such as e-learning, Massive Open Online Course (MOOC), Virtual Learning Environment (VLE), with blended learning methods conducted at some schools as well as the integration of mobile devices (m-learning) and online education applications (Earle, 2002; El-Sofany, Al-Turki, El-Howimelm, Al-Sadoon, \& El-Seoud, 2013; Le Roux \& Evans, 2011; Spector, 2013). With the intensity of demand of online world, with lack of infrastructures and school budgets, leaves a substantial digital divide between the "haves" and "have nots" among public schools (Li \& Ranieri, 2013; Yusof, Hashim, \& Rashim, 2012). There are over 40 million students in America's K-12 public schools falls into digital divide and being left behind in the advantages of digital learning has offered due to lack of internet access, particularly those among rural and low-income communities (Education Super Highway, 2014). In the UK society, more than 12 million people contributing the widened of digital skills gap and do not have the skills to prosper in the digital era (Cellan-Jones, 2015). Over 1.56 million jobs offered in the UK technology sector which so-called as digital tech economy and 4.4 million digital-based jobs will be created for big amount of data, however the digital entrepreneurs are facing difficulties in hiring skilled digital workers (Saran, 2016). It is an urge warning that talent has gone digital beyond the ability to write emails or build an Excel spreadsheet, and more onto the digital skills efficiency and online influences which will lead the left behind group in losing their 
opportunity to compete in future digital workforce or being in any digital organizations, and will be also affecting their future socio-economy status and to the country as a whole (Buggie, 2014).

Malaysia has been proactive bridging the digital divide by allocating RM 3.7 billion in the Ninth Malaysian Plan and the National Broadband Initiative (NBI) puts in place into national strategy to increase broadband usage throughout the country by providing opportunity of ICT access, amongst eligible recipients such as secondary and university students as well as other lower-income groups in rural area (Performance Management and Delivery Unit, 2010). The Rakyat Internet Centres or Community Broadband Centres, 1 Million Netbook for 1.7 million poor students nationwide, E-Kiosks, WiFi Villages and Expansion of Cellular Coverage implemented under this strategy (Malaysian Communications And Multimedia Commission, 2010). Digital Malaysia was launched in year 2012, with the aim to enhance quality-of-life and connecting Malaysian globally, by offering various ICT initiatives to promote pervasive use of ICT in all aspect as well as equipping nation with new skills and capabilities in today's online world to meet the demands of a high-income economy. Other than that, Malaysian Budget 2013 aspproved allocation of RM300 million for Youth Communication Project by offering rebates of RM 200 for 1.5 million poor youth to purchase a $3 G$ smartphone (Malaysian Communications And Multimedia Commission, 2010). These government-led ICT initiatives are mainly attempt to create a society where all of individuals can reach and share information, with the formation of supportive policies to narrowing down the digital divide.

These are also empowered Malaysian adolescents through revolutionized of education by introducing ICT into all schools via policies such as ICT is for all students, by stressing the use of internet for information accession and communication, in creating better future workforce for country's future prosperity (Chan, 2002). Malaysia Education Blueprint 2013-2025 was recently implemented, emphasizing on quality and equity of education to all students, with the aim to increase the integration of ICT in nurturing creativity and innovation among students and preparing them for tomorrow worlds(Ministry of Education Malaysia, 2013). Specifically, this plan targeting on 50\% reduction in achievement gaps (urban-rural, socio-economic, and gender) by 2020, increase Bilingual Proficiency among students, enhancing Ethics and Spirituality, empowering students thinking skill as well as notion their leadership skill and knowledge gaining via ICT.

Additionally, to broader educational equity in ICT, School Computerization Project invested by developing 9593 computer labs in each secondary schools (Educational Technology Division, 2011). Computer in Education Programme enforced by providing ICT training for teachers and students with the forge of ICT and ICTL subject as an elective subject for most schools in rural and urban areas as well as Electronic Book (e-Book) project in replacing conventional textbooks to solve heavy school-bags problem (Umar \& Hussin, 2014; Umar \& Jalil, 2012). During year 2014, Ministry of Education has introduced Mobile laboratory concept in secondary schools with approach 'One Laptop One Student' that applied under the Project of Chromebook Supply. This project was supplying ICTs equipment and 116,399 Chromebooks to eligible students from lower income family and rural areas students, to ensure their complete access to the Virtual Learning Environment (VLE) and internet access at any time and at anywhere (Jabatan Pendidikan Selangor, 2014). 
Despite of all these Malaysian government initiative in enhancing social inclusion on internet accession, previous study illuminating digital divide persist existence among Malaysian secondary school student between genders (male and female) and geographical areas (urban and rural), where by disadvantage groups are associated to females and rural students (Kamarunzaman et al., 2011; Umar \& Jalil, 2012). These digital have-nots groups usually suffers from digital divides and tend to be excluded as well in the social-economic development, and facing great danger of being left behind in this 21st Century modernity (Sparks, 2013). Insufficient digital skills will lead future Malaysian losing opportunities, benefits and advantages that internet has to offer and having difficulties in adapting to the workforce requirements of the new world environments (Deursen, Courtois, \& Dijk, 2014)

Digital divides existence may lead Malaysian future nation setback from the digital future and act as barriers for the technology, politic, social and economic development in Malaysia. Therefore, it is important to conduct study of digital divide by mean of Malaysia context, for better comprehension on the characteristics of groups who suffer from the differences and how well the adolescents are prepared for the digital future, as well as into what extent the bridging efforts has achieved for future action to be taken. This study will rivet to divide in digital skill which skills that are related to internet skills and handling digital devices. There are still lacks of study being done in measuring digital skills in Malaysia which previously studies were only focusing on computer literacy and less emphasizing the internet skill that has grew as demanded skills in today's worlds.

\section{Literature Review \\ Digital Skills}

In an over-saturated environment of Internet connections, focus on the digital divide has shifted away from internet physical access to its skills or usage. The differences in skills has been an important aspect of social inequality, in the use of new communication technologies media such as social network, cloud storage, and the web 2.0 sites as well as digital devices (Gui \& Argentin, 2011). There are various labels used to describe the information and technology skills such as ICT skills, technology skills, 21st century skills, information literacy, digital literacy and digital skills which used to describe skills and competencies in using digital technologies (Ferro, Helbig, \& Gil-Garcia, 2011; Tustin, Goetz, \& Basson, 2012). According to Van Deursen, Van Dijk, and Peters (2012), one of the most important factors in digital inequalities is the differential possession of digital skills that combining those skills needed for personal computers, mobile phones or digital devices and for the internet. Digital skills consisted of few dimension; operational skills, information navigation skills, social skills, creative skills and mobile skills (Van Deursen, Helsper, \& Eynon, 2014).

Operational skills referred as competencies that are related to the ability to use and control the network software such as the browsers, operating internet-based search engines and operating internet-based forms (Deursen et al., 2014). Information navigation skills deprived from the information-literacy, which could be declare as skills to search, select and recognized information that is needed and locate, use or re-use the information found effectively, and evaluating information in digital media with the abilities to handle the special structures of digital media such as menus and hyperlinks (Van Deursen et al., 2014). Social skills refers to skills in 
safely socializing in digital worlds in which lacking of this skills, may create social inequalities in a development of a country, society engagement as well as participation and collaboration in education life and online public sphere as a whole (Radovanovic, 2012). In order to be part of society nowadays and meeting the social expectation, skills in socializing and communicating in the online platform are really needed especially in interpreting online messages, selectiveness in sharing information, as well in constructing, understanding, and exchanging meanings with each other (Castek \& Beach, 2013). Creative skills with the regard to the content creation skills and web development skills refers to the abilities of producing user-generated content in acceptable quality to be published online, by making, editing, remixing various types of media formats such as textual, music and video, photo or image, multimedia and remixed content (Van Deursen et al., 2014). With today's online democracy and diversity, adolescents could easily create their own content, as well as receiving news and entertainment from millions of online outlets (West \& West, 2015). This mass cultural production of electronic user-generated content has proliferated on the internet, creating new digital inequality from a production lens (Livingstone \& Helsper, 2010). For some, it has brought people out of isolation, whether geographically or personally. With the highly content sharing among adolescents, with highly electronically and virtually participation in this 'social networking era', digital skills should be mastered by one, in order to wipe out the digital inequality.

The widespread uses of mobile devices has enables information and knowledge rapidly access, communicates and stay connected with each other's at any place, at any time. Mobile devices includes portable digital devices such as mobile phones, smart phones, handheld PCs, tablets, iPad, and netbooks, that are able to run mobile applications the ability to be wirelessly internet connected. Lacking of networks facilities will limiting what one can do with these devices. Internet access and computing capabilities have been built into the mobile device, where already users of these ICTs can simply transfer the skills using the computer into the mobile devices (James, 2009). Therefore, whom who do not already possess the necessary skills and knowledge to use them, will be effectively prevented from accessing it and caused them falls into the disadvantage groups (Wijetunga, 2014). In addition, disengagement from this new communication technology could lead to social, cultural and economic exclusion too (Lee, Park, \& Hwang, 2015). Mobile skills are the last dimension of digital skills that considered to be mastered by the young generation today, in order to bridge the gap. Lee et al. (2015) argued that mobile skills should had its own measurement in order to measure people skills in handling, using or operating mobile devices as it has its own divide. However, Van Deursen et al. (2014), decided mobile skills should not be apart from internet skills, and only as separate scale in the measurement as the skills is necessary to able someone to mastered other networking skills.

\section{Divide in Digital Skills}

The immersion of internet connections widely and keep evolving rapidly, has made online activities requires students to have more skills for effectively and efficiently used. Developing internet skills among secondary school students are increasingly important for full participation in a knowledge-based society (Li \& Ranieri, 2013). Education levels appears to be the most relevant factor connected to differences in digital skills, while age remain as constant factors in inequalities of digital skills and gender showed significant impact on the level of self-perceived 
skills and knowledge on web-related terms (Van Deursen \& Van Dijk, 2011). However, research that compares gender in their ability to solve actual tasks online demonstrates little disparity (Van Deursen \& Van Dijk, 2008). It is crucial to understand the diversity among young people in terms of skills, when it comes to what they know about and what they are able to do with internet technology (Davies, 2011; Litt, 2013).

Study by Gui \& Argentin (2011), shows that gender do generate inequality in digital skills however it is not for all the dimensions, in which males only performed better than females in one dimension. It is synchronized with other findings in developed countries, that there were no gender significant differences in digital skills, but only differences in online experiences whereby male had higher than its counterpart (Van Deursen \& Van Dijk, 2010; Van Deursen \& Dijk, 2008; Livingstone \& Helsper, 2010). Females were also reported using Internet less frequently than the males and had clearly lower level of digital skills (Ferro et al., 2011; Hargittai, 2010). Males were more skillful in dimension of operational skills and use more computers than the female does (Hew \& Leong, 2011). This is due to that females were less affluent, less access to internet devices as well as reported having lower education which only at elementary level (Lee et al., 2015). This is also may due to computer experience has a positive impact on decreasing the computer anxiety for males in the computer and internet-liking factors, but not effected for females (Broos, 2005). Novo-Corti, Varela-Candamio, and Garcia-Alvarez (2014) added that mostly females were lack of digital skills due to their negative attitudes towards ICT. Despite of that, females among the secondary school students showed higher digital skills level than the male students (Lau \& Yuen, 2014).

According to Hatlevik and Christophersen (2013) gender-differences should be revised as when gender is controlled, both genders perform equal digital skills. In developing countries, even though male uses ICT twice higher than females, but females uses internet more than males, and when the inequalities of access is controlled, females embrace digital technology more enthusiastically than male (Hilbert, 2011). There are also no differences in internet usage except male tend to be more engage for online entertainment and leisure activities (Milioni, Doudaki, \& Demertzis, 2014). Contradict with findings by Van Deursen and Van Dijk (2013) whereby females are more engage in online games. However, females proved the highest usage of internet for educational purposes and social network sites than the boys (Mascheroni \& Olafsson, 2015). In the context of Malaysia, inequalities by mean of digital skills exist between genders whereby females likely having low competencies than males (Hew \& Leong, 2011). Majority of secondary school students in Malaysia were having access to the internet as well as the digital devices, but they were more involves in online socializing activities, communicating with friends and relatives, such as via the voice call, texting and messaging, blogging, social networking, online chatting in some cases via webcam as well as the mobile social apps (Umar \& Jalil, 2012).

Lacking of digital skills will cause the disadvantageous group losing the wide opportunities that have offered by the internet such as getting offered for scholarships and studying at best institution, as most admission and advertisements are going online (Livingstone \& Helsper, 2010). Previous study proved that students with higher digital skills leads them achieve higher in academic performances with varieties of source supports and information and references they could get through online from outside world friends and expert or via self-exploratory learning (Zhao, Lu, Huang, \& Wang, 2010). Low academic achiever will not be accepted to pursue their 
study on tertiary education, therefore close-minded people increases and chances to be in higher income groups are lower, in which will caused them staying at low cost residency such as at rural areas. They also may suffered from good health hospitality due to lack of money to pay health cost, and with lack of money may leads them involves in negative activities such as robbery, prostitution and drug dealers that soon threatened Malaysian peace and economy (Soh, Yan, Ong, \& Teh, 2012). Supported by Lau and Yuen (2014), online skills are closely related to other literacies, such as numeracy and reading, and to other cognitive skills, and its development is crucial. Lower levels of academic performances students may use internet in different ways, which it may put them in higher risk on cybercrime and negative online usage such as gambling, bullying, internet abuse and addiction, negative ideology leads to terrorism, pornography, mental and health problems, rape and suicides that will destroy their future as Malaysian headway drivers. Thus digital skills inequality were proven produces gap among young generation in education, social and economy especially implications for their personal development (Li \& Raneri, 2013).

\section{Method}

This study applied survey design which involved 342 secondary students from regular national schools in Hulu Langat districts, Selangor with average age of 16 years-old. Sample size was determined using Cochran's calculation and proportionate stratified random sampling technique. The questionnaires (refer appendix) were randomly distributed among schools selected that met criteria such had the ICT facilities (computer laboratory and access center) provided by the Ministry of Education and availability of ICT training class (ICT and ICTL subject) and only 292 respondents' scores used in study after EDA analysis for further SPSS analysis. Descriptive, independent t-test and Pearson's correlation analysis were used. The criterion were set to avoid bias that might affect data accuracy, thus digital skills were measured among schools who had equal ICT facilities and ICT exposure.

The questionnaire consist 83 items of three section; A (demography), B (ICT demography) and $C$, consist of 68 items measuring on the six dimension of digital skills with few items were adopt and adapt from several previous study (Flower \& Algozzine, 2000; Oulasvirta, Wahlstrom, \& Ericsson, 2011; Park \& Mo Jang, 2014; Park, 2014; Sung, 2015; Zhao et al., 2010). All dimensions were above reliability value of Cronbach's alpha .7 where averagely each dimension obtained values are higher than .8. Computer operational skills were using four Likert scale ranging from 1 (not competent) to 4 (very competent) and most items remained the original five-Likert scale by Van Deursen et al. (2014) with additional option of "I don't understand the question" to provide flexibility if respondents who do not know certain skills. The questionnaire was originally developed in the English language and administered in Malay language, to accommodate respondents' convenience and understanding of the questionnaire which was subjected to backto-back translation. Mean scores of each items in each dimension then computed, interpreted as in table 1 below. 
INTERNATIONAL JOURNAL OF ACADEMIC RESEARCH IN PROGRESSIVE EDUCATION AND DEVELOPMENT

Vol. 8, No. 4, 2019, E-ISSN: 2226-6348 @ 2019 HRMARS

Table 1: Mean distribution interpretation

\begin{tabular}{cc}
\hline Range mean scores & Indicators level \\
\hline $4.5-5$ & Very High skill \\
$3.5-4.4$ & High skill \\
$2.5-3.4$ & Moderate skill \\
$1.5-2.4$ & Low skill \\
1.4 & Almost no skill \\
\hline
\end{tabular}

Source : (Umar \& Jalil, 2012).

\section{Result and Discussion}

\section{Respondents Overall Profile}

292 students data used for result findings, 53.8\% (157) are female students. Malay students were $54.5 \%$ (159) of the respondents, followed by Chinese (33.9\% or 99 students), Indians (10.3\% or 30 students) and other ethnic group (1.4\% or 4 students). Majority of the students were from urban schools (70.9\% or 207 students) and the rest from rural schools $(29.1 \%$ or 85 students). Majority students among lower (36\% or 105 students) and middle (36.3\% or 106 students) income family, and whereby majority of their parents' highest educational level were at high school level (51.7\% or 151 students). Majority of $35.5 \%$ or 103 students were in other type of stream whereby 46 male students (29 urban students and 17 urban students) and 57 female students ( 25 urban students and 32 rural students) followed by $33.6 \%$ or 98 students in science stream, composition of 44 male students (29 urban students and 15 rural students) and 54 female students (none among rural students). Class stream is related with academic achievements, as in Malaysia, usually students with good grades will be assigned in science stream. 
INTERNATIONAL JOURNAL OF ACADEMIC RESEARCH IN PROGRESSIVE EDUCATION AND DEVELOPMENT

Vol. 8, No. 4, 2019, E-ISSN: 2226-6348 @ 2019 HRMARS

Table 2:Demography distribution

\begin{tabular}{|c|c|c|c|c|c|}
\hline & \multirow{2}{*}{\multicolumn{3}{|c|}{ Measure }} & Frequenc & $\%$ \\
\hline & & & & y & \\
\hline & \multirow[t]{2}{*}{ Gender } & \multicolumn{2}{|l|}{ Male } & 135 & 46.2 \\
\hline & & \multicolumn{2}{|l|}{ Female } & 157 & 53.8 \\
\hline & \multirow[t]{4}{*}{ Race } & \multicolumn{2}{|l|}{ Malay } & 159 & 54.5 \\
\hline & & \multicolumn{2}{|l|}{ Chinese } & 99 & 33.9 \\
\hline & & \multicolumn{2}{|l|}{ Indian } & 30 & 10.3 \\
\hline & & \multicolumn{2}{|l|}{ Others } & 4 & 1.4 \\
\hline & \multirow[t]{2}{*}{ Area } & \multicolumn{2}{|l|}{ Urban } & 207 & 70.9 \\
\hline & & \multicolumn{2}{|l|}{ Rural } & 85 & 29.1 \\
\hline & $\begin{array}{l}\text { Parents' income } \\
\text { (RM) }\end{array}$ & \multicolumn{2}{|c|}{ Lower $(<2500)$} & 105 & 36 \\
\hline & & \multicolumn{2}{|c|}{ Middle $(<4500)$} & 106 & 36.3 \\
\hline & & \multicolumn{2}{|c|}{ High Modest $(<5500)$} & 26 & 8.9 \\
\hline & & \multicolumn{2}{|c|}{ High $(<7500)$} & 33 & 11.3 \\
\hline & Parent's education & \multicolumn{2}{|c|}{ Elementary } & 40 & 13.7 \\
\hline & & \multicolumn{2}{|c|}{ High school } & 151 & 51.7 \\
\hline & & \multicolumn{2}{|c|}{ Diploma } & 40 & 13.7 \\
\hline & & \multicolumn{2}{|l|}{ Degree } & 31 & 10.4 \\
\hline & & \multicolumn{2}{|l|}{ Master } & 6 & 1.9 \\
\hline & & \multicolumn{2}{|c|}{ Doctorate and above } & 1 & 0.2 \\
\hline \multirow{11}{*}{$I C T I C T$} & Language & \multirow[t]{3}{*}{ English } & high & 55 & 18.3 \\
\hline & proficiency & & moderat & 216 & 72 \\
\hline & & & $\begin{array}{l}e \\
\text { weak }\end{array}$ & 22 & 7.3 \\
\hline & & \multirow[t]{4}{*}{ Malay } & high & 120 & 40 \\
\hline & & & moderat & 158 & 52.7 \\
\hline & & & $e$ & 15 & 5 \\
\hline & & & weak & & \\
\hline & & \multirow[t]{4}{*}{ Others } & high & 67 & 22.3 \\
\hline & & & moderat & 53 & 17.7 \\
\hline & & & $e$ & 42 & 14 \\
\hline & & & weak & & \\
\hline
\end{tabular}

\section{Background}

Majority of urban and rural students had ICT training which only $24.9 \%$ (50) of urban students had none ICT training (26 of them are male students and 24 females students) while $23.8 \%$ (20) of rural students did not had any ICT training with only seven of them were female students and 13 male students. 
Vol. 8, No. 4, 2019, E-ISSN: 2226-6348 @ 2019 HRMARS

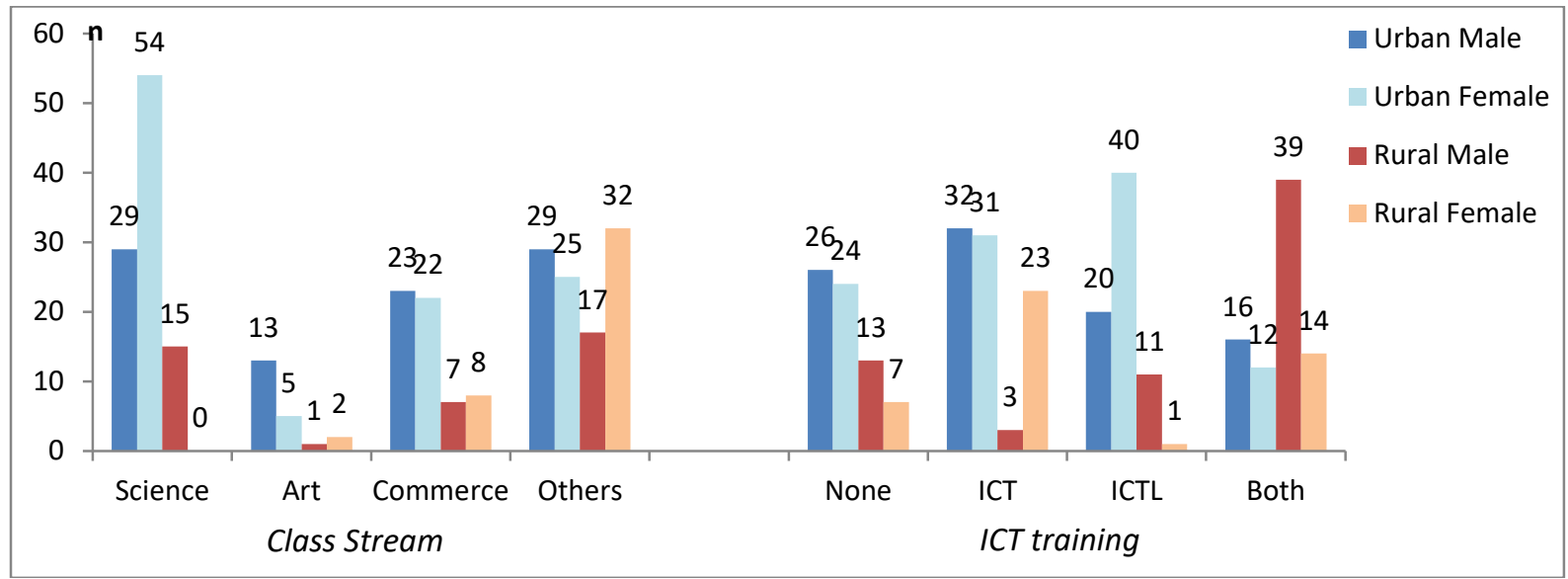

Figure 1: Respondents' class stream and ICT training

Most of $31.3 \%$ (91) students were spending three hours and less for online activities per day, which higher among urban male (28) and urban female (38). In rural area, female students are highly spent time for online activities compared to the male students, whereby they spent mostly around more than three hours and less (19) and more than six hours and less (17). Urban female students (21) are the most group whom spending sixteen hours and more per day for online activities. Majority of 33.9\% (99) students had more than three years of using internet followed by $27.7 \%$ (81) students had more than six years online experiences, and $18.2 \%$ (53) students had more than nine years whereby female (22) are highly experienced than male (8) students for both areas.

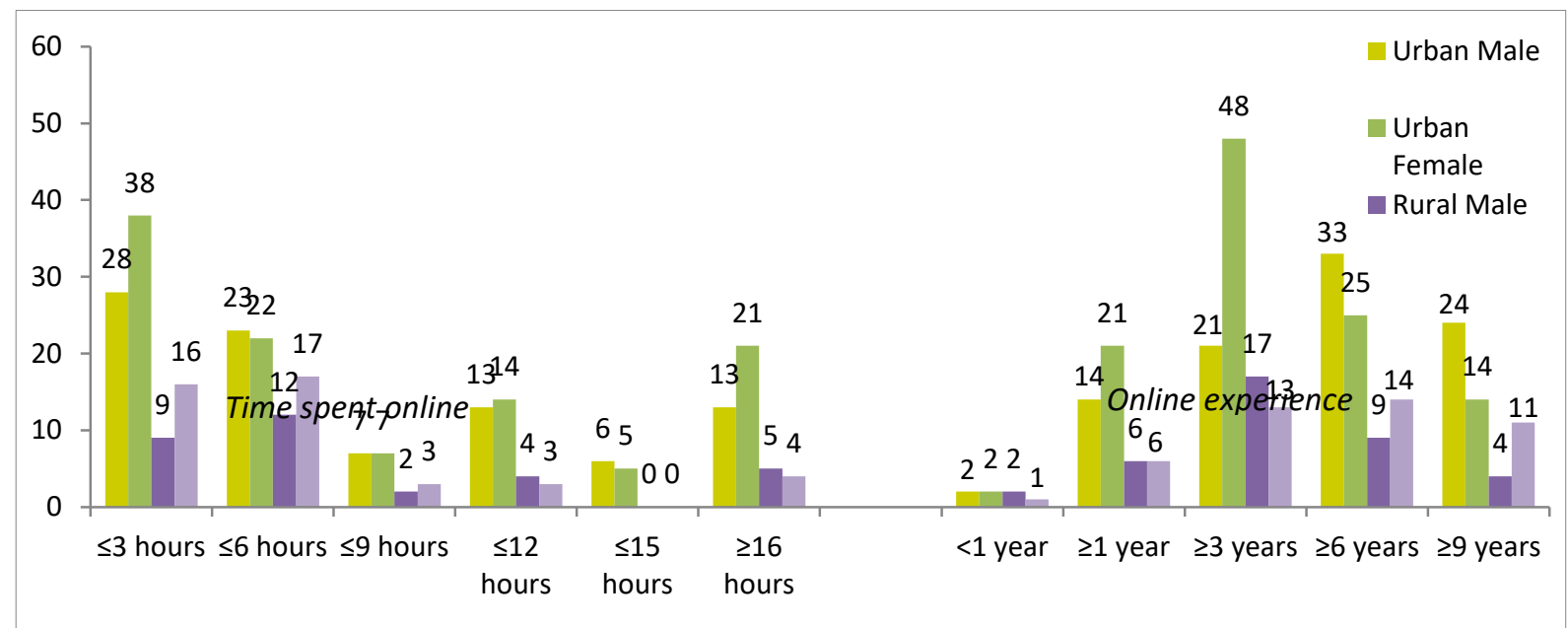

Figure 2:Respondents' time spent online and online experiences.

Majority of $88.3 \%$ (265) students had home internet access whereby $90.6 \%$ (192) of students from urban schools had the access, however majority of them are female (104). Most of $83 \%$ (73) students from rural area had access whereby majority of them are female (37) too. Majority of $88.7 \%$ (259) students owned smartphone and laptop (69.2\%) which mostly owner were among females. Only $40.4 \%$ (118) students had tablet, whereby females (20) owner were 
Vol. 8, No. 4, 2019, E-ISSN: 2226-6348 @ 2019 HRMARS

more than male (9) in the rural area and female (67) in urban area higher than male (58.6) of not having any tablet. Majority of $85 \%$ (255) students have not own any digital devices provide by the government such as Chromebook, 1Malaysia notebook and 1Bestarinet, while only 14.3\% (43) students received it, which mostly among male students in urban area.

Table 3: digital devices ownership

\begin{tabular}{|c|c|c|}
\hline HAVE & & HAVE NOT \\
\hline Urban (n) & Urban (n) & Rural (n) \\
\hline
\end{tabular}

\begin{tabular}{|c|c|c|c|c|c|c|c|c|c|c|c|c|}
\hline & e & e & e & $\mathrm{e}$ & & & e & $\mathrm{e}$ & $\mathrm{e}$ & $\mathrm{e}$ & & \\
\hline $\begin{array}{l}\text { Home Internet } \\
\text { Access }\end{array}$ & 83 & 104 & 33 & 37 & $\begin{array}{c}26 \\
5\end{array}$ & 88.3 & 12 & 8 & 7 & 8 & 35 & 11.7 \\
\hline Smartphone & 87 & 96 & 36 & 40 & $\begin{array}{c}25 \\
9\end{array}$ & 88.7 & 9.9 & 12 & 4 & 5 & 29 & 9.9 \\
\hline Computer & 55 & 60 & 23 & 24 & $\begin{array}{c}16 \\
2\end{array}$ & 55.5 & 43.8 & 50 & 17 & 21 & $\begin{array}{c}12 \\
8\end{array}$ & 43.8 \\
\hline Laptop & 66 & 79 & 26 & 31 & $\begin{array}{c}20 \\
2\end{array}$ & 69.2 & 30.1 & 31 & 14 & 14 & 88 & 30.1 \\
\hline Tablet & 47 & 42 & 9 & 20 & $\begin{array}{c}11 \\
8\end{array}$ & 40.4 & 58.6 & 67 & 31 & 25 & $\begin{array}{c}17 \\
1\end{array}$ & 58.6 \\
\hline Gov.Incentive & 16 & 12 & 9 & 5 & 43 & 14.3 & 85 & 98 & 31 & 40 & $\begin{array}{c}25 \\
5\end{array}$ & 85 \\
\hline
\end{tabular}

\section{Digital Skills}

In order to trace digital divide existences among secondary school students, two-fold of independent sample t-Test analysis were done. As the first, differences among overall males and females, then analysis were done among genders in urban and among genders in rural areas. Results were generated as in table 4, whereby there were significant differences in digital skills level in all dimension of digital skills except for social skills. This interprets that digital skills inequalities do exist in all dimension and male and females were only equally in social skills. Male secondary students had higher level than female students, in almost all of skills such in computer skills, internet operational skills, creative skills and mobile skills, even though the numbers of female respondents are higher than males. However, female students $(M=3.36)$ are highly skilled in information navigation dimension than male students $(M=2.98)$ with small significant differences $\left(\eta^{2}=.02\right.$ ) according to Cohen's eta-squared $\left(\eta^{2}\right)$ interpretation (1988).

There are skills differences in all dimensions of digital skills among genders in urban area except for mobile skills, whereby urban male had higher skills level than urban female students in computer operational $\left(\eta^{2}=.06\right.$, medium), internet operational and creative skills $\left(\eta^{2}=.04\right.$, small), while female had higher skills in information navigation $\left(\eta^{2}=.04\right.$, small) and social $\left(\eta^{2}=\right.$ .03 , small), and both genders in urban area had similar level of mobile skills.

Female are highly skilled in information navigation and social, may due to several reasons, such as females students were more exposed to information world, naturally as active information-seekers, due to their high curiosity about things, people and keen to know in details 
and good in manipulating information compared to males (Geary, 2015). This also proven finding by Tustin et al. (2012), whereby females engage more in internet activities related to online newspaper or magazine reading. Female students likely to use internet frequently for information searching in finding study-related materials than male students who involves more in entertainment activities (Drabowicz, 2014; Li \& Ranieri, 2013).

According to Milioni et al., (2014), communication, content creation and sharing is affected by area where urban areas higher than the rural. This may complimented by the nature of female adolescents tend to be more socially perceptive than male, where they use internet more in socializing and interaction thus their social literacy increased (Ram, Strohschein, \& Gaur, 2014). Females students are normally better at communication and social thinking, likely having more friends list, making new friends virtually, commenting frequently, sharing information about themselves more as well as following their friends' pages in social network while male students likely to involve more in online gaming and watching online videos or movies (Drabowicz, 2014). This finding is echoing study by Hew and Leong (2011), where males more skillful in technical computer skills than females. Males tend to be braver, task-oriented and risktaker to handle and operates physical technical things compared to female students, and this proved by the higher number of urban males in other stream such as technic and vocational stream.

Male were high in creative skills, may due to nowadays digital technologies are supporting the creation skills of one's (Grant, 2011) and male tend to have higher perceiveness and rated themselves as highly creative (Devon, Aaron \& Christy, 2015). This proved by statistic portal (Statista, 2012), where interest in online content creation is constantly increasing especially in recorded short videos and uploaded videos or photos in which the engagement are higher across male adolescents. In addition, internet trend do influences male online creative skills where recent trending among secondary male students in creating and posting parody and troll videos online, in seeking more likes and comments as well as public attention to be famous and wellknown by having their own channels and followers (Vedantham, 2012). The trends seems becoming a habit of teenagers nowadays in sharing video especially among male. If this trend is not fully monitored and control, it may lead to online harassment and internet trolling by mocking other parties, where cyber bullying nation will soon be widely breed.

As for gender digital divide in rural areas, it exist only in three dimension of digital skills; internet operational skills ( $\eta^{2}=.06$, medium), creative skills $\left(\eta^{2}=.07\right.$, medium), and mobile skills $\left(\eta^{2}=.06\right.$, medium) whereby male had higher skills than female students even though genders is controlled. Male higher in mobile skills may due to exploratory behaviour, where male tend to explore their mobile devices setting more than the female students (Davies, 2011). This also may due to male students' interest own gadgets such as getting the latest and better mobile devices, thus lead them to own one by collecting own money or insist their parent to buy one. 
INTERNATIONAL JOURNAL OF ACADEMIC RESEARCH IN PROGRESSIVE EDUCATION AND DEVELOPMENT

Vol. 8, No. 4, 2019, E-ISSN: 2226-6348 @ 2019 HRMARS

Table 4: Independent sample t-test on gender

\begin{tabular}{|c|c|c|c|c|c|c|c|}
\hline Skills & Gender & $n$ & Mean & SD & $t$ & Sig- $t$ & $\eta^{2}$ \\
\hline \multirow[t]{2}{*}{ Computer operational } & Male & 134 & 3.51 & .491 & \multirow{2}{*}{3.96} & \multirow{2}{*}{.000} & \multirow{2}{*}{.05} \\
\hline & Female & 156 & 3.28 & .544 & & & \\
\hline \multirow[t]{2}{*}{ Urban } & Male & 95 & 3.54 & .497 & \multirow{2}{*}{3.86} & \multirow{2}{*}{.000} & \multirow{2}{*}{.06} \\
\hline & Female & 112 & 3.25 & .556 & & & \\
\hline \multirow[t]{2}{*}{ Rural } & Male & 39 & 3.45 & .478 & \multirow{2}{*}{1.25} & \multirow{2}{*}{.215} & \\
\hline & Female & 44 & 3.31 & .516 & & & \\
\hline \multirow[t]{2}{*}{ Internet operational } & Male & 133 & 4.3 & .699 & \multirow{2}{*}{3.85} & \multirow{2}{*}{.000} & \multirow{2}{*}{.05} \\
\hline & Female & 150 & 3.98 & .706 & & & \\
\hline \multirow[t]{2}{*}{ Urban } & Male & 94 & 4.33 & .689 & \multirow{2}{*}{2.89} & \multirow{2}{*}{.004} & \multirow{2}{*}{.04} \\
\hline & Female & 107 & 4.06 & .654 & & & \\
\hline \multirow[t]{2}{*}{ Rural } & Male & 39 & 4.24 & .726 & \multirow{2}{*}{2.63} & \multirow{2}{*}{.01} & \multirow{2}{*}{.06} \\
\hline & Female & 43 & 3.79 & .8 & & & \\
\hline \multirow[t]{2}{*}{ Information Navigation } & Male & 132 & 2.98 & 1.34 & \multirow{2}{*}{-2.64} & \multirow{2}{*}{.009} & \multirow{2}{*}{.02} \\
\hline & Female & 151 & 3.36 & 1.12 & & & \\
\hline Urban & Male & 93 & 3.00 & 1.36 & & 005 & 04 \\
\hline & Female & 107 & 3.49 & 1.11 & -2.01 & JuJ & .04 \\
\hline Rural & Male & 39 & 2.92 & 1.29 & & & \\
\hline & Female & 44 & 3.05 & 1.07 & -.471 & .639 & \\
\hline Social & Male & 135 & 4.09 & .767 & 656 & 512 & \\
\hline & Female & 154 & 4.15 & .791 & סכ0. & .J1L & \\
\hline Urban & Male & 95 & 4.02 & .793 & -21 & 038 & 03 \\
\hline & Female & 109 & 4.24 & .721 & -2.1 & .030 & ת. \\
\hline Rural & Male & 40 & 4.26 & .677 & 186 & & \\
\hline & Female & 45 & 3.94 & .912 & 1.80 & .000 & \\
\hline Creative & Male & 135 & 3.38 & 1.05 & 386 & م०० & 05 \\
\hline & Female & 156 & 2.93 & .912 & 3.00 & .000 & כ. \\
\hline Urban & Male & 95 & 3.33 & 1.06 & 264 & 009 & 04 \\
\hline & Female & 112 & 2.96 & .917 & 2.04 & .005 & .04 \\
\hline Rural & Male & 40 & 3.50 & 1.01 & & & \\
\hline & Female & 44 & 2.86 & .905 & 3.08 & .003 & .07 \\
\hline Mobile & Male & 133 & 4.22 & .715 & 249 & 013 & 03 \\
\hline & Female & 154 & 4.01 & .733 & 2.49 & .013 & .05 \\
\hline Urban & Male & 93 & 4.20 & .739 & 1.47 & 144 & \\
\hline & Female & 111 & 4.05 & .732 & & & \\
\hline Rural & Male & 40 & 4.25 & .663 & 24 & 019 & \\
\hline & Female & 43 & 3.89 & .731 & 2.4 & .019 & .00 \\
\hline
\end{tabular}

$* * p=.05$ (two-tailed) 
These findings requires urge attention, whereby females in rural areas are still among the disadvantageous group, even though the inequalities only varies in three dimension of digital skills compared to the genders inequalities among urban students, which in five dimensions more. Rural gender differences considered more critical as the significant differences had reached to medium while genders' skills differences in urban area most were only small differences.

The differences may due to numbers of rural female students were having lower ICT training than the male students, which rural male students are equipped with both ICT and ICTL training. This is also may due to the level of academic achievement among rural female students are lower than the rural male, as rural female majority in other class stream while rural male higher in science class. Amount of hour spent online of rural females are lower than rural male students, may contribute to this differences. Even though, the years of online experiences among rural females are higher than the rural male students, yet they still had lower skill. This is similarly with finding by Van Deursen, van Dijk, \& Peters (2011), that years of online experience doesn't contributes to one's skills level. Nevertheless, more initiatives needed in empowering female students to be more digital savvy.

\section{Conclusion}

Even though ICTs are having ever greater impact on global economies and social processes, having a widening divide is hazardous on many levels, especially when technology is a primary driver for productivity, growth and efficiency of a country, it may lead to retrogression. The issue of digital divide in Malaysia indeed need serious attention after all the initiatives being done with huge amount of money spent in developing the techno-structure and ICT education programs. Even though government have provide nation with techno-infrastructure, the digital divide won't end. It is rather to enhance skills by educating them, creating, developing and fostering knowledge in the societies with more efficient strategies and program (Radovanovic, 2012). This is also to prepare the future Malaysian's workforce to adapt with the requirements of the new digitalized world. More training should be taught in schools especially among the disadvantageous groups, by emphasizes more on cybersecurity, cyber risk management, online safety and personal privacy. Education should also foster digital creativity and innovation, by providing students with the opportunity to test and experiment with the technology. Education system should systematically and strategically developed future digital skill among the students for today's requirements of digital organization. Digital skills are essential tool that underpins other subjects and should be considered as complimentary to the numeracy and literacy.

The findings stipulates the need for more academic research to illuminate why is the gap exist, how it evolves, what it will caused and how formal education and ICT infrastructures will works on bridging the gap (Soh et al., 2011; Sparks, 2013). Therefore, more investigation in digital divide needed in Malaysia context, by mean of digital skills among rural and urban areas and it is an urgent task to track its development that subject to modification, to solve it before becoming serious. 
INTERNATIONAL JOURNAL OF ACADEMIC RESEARCH IN PROGRESSIVE EDUCATION AND DEVELOPMENT

Vol. 8, No. 4, 2019, E-ISSN: 2226-6348 ㄷ 2019 HRMARS

\section{Acknowledgement}

This work was financially supported by Ministry of Higher Education Malaysia via MyBrain15 initiatives.

\section{Corresponding Author}

Ahmad Fauzi Mohd Ayub (PhD), Faculty of Educational Studies, Universiti Putra Malaysia (UPM), 43300 Serdang, Selangor MALAYSIA

Email: afmy@upm.edu.my

\section{References}

Broos, A. (2005). Computer experience has a positive impact on decreasing computer anxiety for men, but a similar effect was not found for women. The model was also tested for computer liking and Internet-liking factors. CyberPsychology \& Behavior, 8(1), 21-31. doi:10.1089/cpb.2005.8.21

Buggie, M. (2014). The Digital Talent Gap: Developing Skills for Today's Digital Organizations. Capgemini. Retrieved from https://www.capgemini.com/resources/video/the-digitaltalent-gap-developing-skills-for-todays-digital-organizations

Carvalho, D., Bessa, M., Oliveira, L., Guedes, C., Peres, E., \& Magalhaes, L. (2012). New Interaction Paradigms to Fight the Digital Divide: A Pilot Case Study Regarding Multi-Touch Technology. Procedia Computer Science, 14(Dsai), 128-137. doi:10.1016/j.procs.2012.10.015

Castek, J., \& Beach, R. (2013). Using Apps to Support Disciplinary Literacy and Science Learning. Journal of Adolescent \& Adult Literacy, 56(April), 554-564. doi:10.1002/JAAL.180

Cellan-Jones, R. (2015). More than 12 million fall into UK digital skills gap. BBC News, $p$. Technology. Retrieved from http://www.bbc.com/news/technology-34570344

Chan, F. M. (2002). ICT in Malaysian Schools: Policy and Strategies. Ministry of Education Malaysia.

Davies, C. (2011). Digitally strategic: how young people respond to parental views about the use of technology for learning in the home. Journal of Computer Assisted Learning, 27, 324-335. doi:10.1111/j.1365-2729.2011.00427.x

DeWitt, D., \& Siraj, S. (2010). Design and development of a collaborative mlearning module for secondary school science in Malaysia: Addressing learners' needs of the use and perceptions of technology. In Procedia - Social and Behavioral Sciences (Vol. 2, pp. 471-475). doi:10.1016/j.sbspro.2010.03.046

Drabowicz, T. (2014). Gender and digital usage inequality among adolescents: A comparative study of 39 countries. Computers and Education, 74, 98-111.

doi:10.1016/j.compedu.2014.01.016

Earle, R. S. (2002). The Integration of Instructional Technology into Public Education : Promises and Challenges, 42(1), 5-13.

Education Super Highway. (2014). Connecting America's Students: Opportunities for Action. United State of America. Retrieved from http://www.educationsuperhighway.org/wpcontent/uploads/2014/11/Connecting-Americas-Students-K12-E-rate-Spending-ReportApril-2014.pdf

Educational Technology Division. (2011). Computer Lab Project. Ministry of Education. Retrieved 
INTERNATIONAL JOURNAL OF ACADEMIC RESEARCH IN PROGRESSIVE EDUCATION AND DEVELOPMENT

Vol. 8, No. 4, 2019, E-ISSN: 2226-6348 @ 2019 HRMARS

March 29, 2015, from http://www.moe.edu.my/btp/wp-content/uploads/2011/01/ProjekMakmal-Komputer.pdf

El-Sofany, H. F., Al-Turki, T., El-Howimelm, H., Al-Sadoon, A., \& El-Seoud, S. A. (2013). Improving Educational Outcomes by Providing Educational Services through Mobile Technology. International Journal of Interactive Mobile Technologies, 7(1), 25-30. doi:10.3991/ijim.v7i1.2287

Ferro, E., Helbig, N. C., \& Gil-Garcia, J. R. (2011). The role of IT literacy in defining digital divide policy needs. Government Information Quarterly, 28(1), 3-10. doi:10.1016/j.giq.2010.05.007

Ghobadi, S., \& Ghobadi, Z. (2015). How access gaps interact and shape digital divide: a cognitive investigation. Behaviour \& Information Technology, 34 (4)(October), 330-340. doi:10.1080/0144929X.2013.833650

Grant, L. (2011). "I"m a completely different person at home': using digital technologies to connect learning between home and school'. Journal of Computer Assisted Learning, 27, 292-302. doi:10.1111/j.1365-2729.2011.00433.x

Gui, M., \& Argentin, G. (2011). Digital skills of internet natives: Different forms of digital literacy in a random sample of northern Italian high school students. New Media \& Society, 13(6), 963-980. doi:10.1177/1461444810389751

Hargittai, E. (2010). Digital Na(t)ives? Variation in internet skills and uses among members of the "net Generation." Sociological Inquiry, 80(1), 92-113. doi:10.1111/j.1475682X.2009.00317.x

Hatlevik, O. E., \& Christophersen, K. A. (2013). Digital competence at the beginning of upper secondary school: Identifying factors explaining digital inclusion. Computers and Education, 63, 240-247. doi:10.1016/j.compedu.2012.11.015

Hew, T. S., \& Leong, L. Y. (2011). An Empirical Analysis of Malaysian Pre-university Students ' ICT Competency Gender Differences. International Journal of Network and Mobile Technologies ISSN 2229-9114, 2(1), 15-29.

Hilbert, M. (2011). Digital gender divide or technologically empowered women in developing countries? A typical case of lies, damned lies, and statistics. Women's Studies International Forum, 34(6), 479-489. doi:10.1016/j.wsif.2011.07.001

James, M. A. (2009). "Far" transfer of learning outcomes from an ESL writing course: Can the gap be bridged? Journal of Second Language Writing, 18(2), 69-84.

doi:10.1016/j.jslw.2009.01.001

Kamarunzaman, N. Z., Zakaria, Z., Zawawi, A. A., Noordin, N., Sawal, M. Z. H. M., Rahman, A. A., ... Nordin, M. M. (2011). Identifying Gaps in Digital Divide -- Comparison between localities in Sg. Petani, Kedah, Malaysia. Interdisciplinary Journal of Contemporary Research in Business, 3(4), 556-562. Retrieved from

http://proxy1.ncu.edu/login?url=http://search.ebscohost.com/login.aspx?direct=true\&db $=$ bth \&AN=66172114\&site=eds-live

Kate, M. (2015). Bridging the Divide : Using UTAUT to predict multigenerational tablet adoption practices. Media and Communications Faculty Publications.

Kopaiboon, W., Reungtrakul, A., \& Wongwanich, S. (2014). Developing the Quality of ICT Competency Instrument for Lower Secondary School Students. Procedia - Social and 
INTERNATIONAL JOURNAL OF ACADEMIC RESEARCH IN PROGRESSIVE EDUCATION AND DEVELOPMENT

Vol. 8, No. 4, 2019, E-ISSN: 2226-6348 @ 2019 HRMARS

Behavioral Sciences, 116(2009), 1802-1809. doi:10.1016/j.sbspro.2014.01.475

Lau, W. W. F., \& Yuen, A. H. K. (2014). Developing and validating of a perceived ICT literacy scale for junior secondary school students: Pedagogical and educational contributions. Computers and Education, 78, 1-9. doi:10.1016/j.compedu.2014.04.016

Le Roux, C. J. B., \& Evans, N. (2011). Can cloud computing bridge the digital divide in South African secondary education? Information Development. doi:10.1177/0266666911401502

Lee, H., Park, N., \& Hwang, Y. (2015). A new dimension of the digital divide: Exploring the relationship between broadband connection, smartphone use and communication competence. Telematics and Informatics, 32(1), 45-56. doi:10.1016/j.tele.2014.02.001

Li, Y., \& Ranieri, M. (2013). Educational and social correlates of the digital divide for rural and urban children: A study on primary school students in a provincial city of China. Computers \& Education. doi:10.1016/j.compedu.2012.08.001

Litt, E. (2013). Measuring users' internet skills: A review of past assessments and a look toward the future. New Media \& Society, 15(4), 612-630. doi:10.1177/1461444813475424

Livingstone, S., \& Helsper, E. (2010). Balancing opportunities and risks in teenagers' use of the internet: the role of online skills and internet self-efficacy. doi:10.1177/1461444809342697

Malaysian Communications And Multimedia Commission. (2010). Malaysian Communications And Multimedia Commission (MCMC) National Broadband Initiative. Official Portal of MCMC. Retrieved March 29, 2015, from http://www.skmm.gov.my/Sectors/Broadband/National-BroadbandInitiative.aspx?lang=en-US

Mascheroni, G., \& Olafsson, K. (2015). The mobile Internet: Access, use, opportunities and divides among European children. New Media \& Society. doi:10.1177/1461444814567986

Milioni, D. L., Doudaki, V., \& Demertzis, N. (2014). Youth, ethnicity, and a "reverse digital divide": A study of Internet use in a divided country. Convergence: The International Journal of Research into New Media Technologies, 20(3), 316-336. doi:10.1177/1354856513517366

Ministry of Education Malaysia. (2013). Pelan Pembangunan Pendidikan Malaysia 2013-2025. Putrajaya: Ministry of Education Malaysia.

Novo-Corti, I., Varela-Candamio, L., \& Garcia-Alvarez, M. T. (2014). Breaking the walls of social exclusion of women rural by means of ICTs: The case of "digital divides" in Galician. Computers in Human Behavior, 30, 497-507. doi:10.1016/j.chb.2013.06.017

Oulasvirta, A., Wahlstrom, M., \& Ericsson, K. A. (2011). What does it mean to be good at using a mobile device? An investigation of three levels of experience and skill. International Journal of Human Computer Studies, 69(3), 155-169. doi:10.1016/j.ijhcs.2010.11.003

Park, Y. J. (2014). My whole world's in my palm! The second-level divide of teenagers' mobile use and skill. New Media \& Society, 1461444813520302-. doi:10.1177/1461444813520302

Park, Y. J., \& Mo Jang, S. (2014). Understanding privacy knowledge and skill in mobile communication. Computers in Human Behavior, 38, 296-303. doi:10.1016/j.chb.2014.05.041

Performance Management and Delivery Unit (PEMANDU). (2010). Economic Transformation Programme: A Roadmap for Malaysia. Performance Management \& Delivery Unit (Pemandu). doi:10.1002/047167849X.bio071

Plowman, L., Stevenson, O., Stephen, C., \& McPake, J. (2012). Preschool children's learning with 
INTERNATIONAL JOURNAL OF ACADEMIC RESEARCH IN PROGRESSIVE EDUCATION AND DEVELOPMENT

Vol. 8, No. 4, 2019, E-ISSN: 2226-6348 @ 2019 HRMARS

technology at home. Computers \& Education, 59(1), 30-37. doi:10.1016/j.compedu.2011.11.014

Radovanovic, D. (2012). Digital Divide and Social Media: Connectivity Doesn't End the Digital Divide, Skills Do. SSRN Electronic Journal, 1-3. doi:10.2139/ssrn.2001952

Ram, U., Strohschein, L., \& Gaur, K. (2014). Gender Socialization: Differences between Male and Female Youth in India and Associations with Mental Health. International Journal of Population Research. doi:10.1155/2014/357145

Saran, C. (2016). Tech Nation 2016 report reveals demand for digital skills in all sectors. Computer Weekly. Retrieved from http://www.computerweekly.com/news/4500272943/Tech-Nation-2016-report-revealsdemand-for-digital-skills-in-all-sectors

Soh, P. C. H., Yan, Y. L., Ong, T. S., \& Teh, B. H. (2012). Digital divide amongst urban youths in Malaysia - Myth or reality? Asian Social Science, 8(15), 75-85. doi:10.5539/ass.v8n15p75

Sparks, C. (2013). What is the "digital divide" and why is it important? Javnost, 20(2), 27-46. doi:http://javnost-thepublic.org/article/2013/2/3/

Spector, J. M. (2013). Trends and Research Issues in Educational Technology Setting the Stage ? What is learning? ? Stable and persisting changes in what a ? That which is designed to support and facilitate learning and education ? Purposeful application of knowledge, (May).

Star, T. (2015). Samsung's first Malaysian Smart Classroom. The Star. Jeli, Kelantant.

Sung, W. (2015). A Study on the Effect of Smartphones on the Digital Divide. Proceedings of the 16th Annual International Conference on Digital Government Research (dg.o 2015), 276282. doi:10.1145/2757401.2757427

Tustin, D. H., Goetz, M., \& Basson, A. H. (2012). Digital divide and inequality among digital natives: A South African perspective. African Journal of Business Management, 6, 91409150. doi:10.5897/AJBM11.2228

Umar, I. N., \& Hussin, F. K. (2014). ICT Coordinators' Perceptions on ICT Practices, Barriers and its Future in Malaysian Secondary Schools: Correlation Analysis. Procedia - Social and Behavioral Sciences, 116, 2469-2473. doi:10.1016/j.sbspro.2014.01.593

Umar, I. N., \& Jalil, N. A. (2012). ICT Skills, Practices and Barriers of Its Use Among Secondary School Students. Procedia - Social and Behavioral Sciences.

doi:10.1016/j.sbspro.2012.06.494

Deursen, V. A. J. A M., Dijk, V. J. A G. M., \& Peters, O. (2011). Rethinking Internet skills: The contribution of gender, age, education, Internet experience, and hours online to mediumand content-related Internet skills. Poetics, 39(2), 125-144. doi:10.1016/j.poetic.2011.02.001

Deursen, V. A. J. A.M., Helsper, E. E. ., \& Eynon, R. (2014). Measuring digital skills. From Digital Skills to Tangible Outcomes project report. Retrieved from http://www.utwente.nl/gw/mco/bestanden/ICA2008.pdf

Deursen, V. A. J. A. M., \& Dijk, V. J. A. G. M. (2011). Internet skills and the digital divide. New Media \& Society. doi:10.1177/1461444810386774

Deursen, V. A. J. A. M., Courtois, C., \& Dijk, V. J. A. G. M. (2014). Internet skills, sources of support, and benefiting from Internet use. International Journal of Human-Computer Interaction, 30(4), 278-290. doi:10.1080/10447318.2013.858458 
Deursen, V. A. J. A. M., \& Dijk, V. J. A. G. M. (2013). The digital divide shifts to differences in usage. New Media \& Society, 16, 507-526. doi:10.1177/1461444813487959

Deursen, V. A. J. A. M., Dijk, V. J. A. G. M., \& Peters, O. (2012). Proposing a Survey Instrument for Measuring Operational, Formal, Information, and Strategic Internet Skills. International Journal of Human-Computer Interaction, 28(12), 827-837. doi:10.1080/10447318.2012.670086

Dijk, V. J. A. G. M. (2012). The evolution of the digital divide: The digital divide turns to inequality of skills and usage. Digital Enlightenment Yearbook 2012, 57-75. doi:10.3233/978-1-61499057-4-57

West, B. D. M., \& West, D. M. (2015). Digital divide: Improving Internet access in the developing world through affordable services and diverse content, (February).

Wijetunga, D. (2014). The digital divide objectified in the design: Use of the mobile telephone by underprivileged youth in Sri Lanka. Journal of Computer-Mediated Communication, 19, 712726. doi:10.1111/jcc4.12071

Wong, C. Y., Khong, C. W., \& Chu, K. (2012). Interface Design Practice and Education Towards Mobile Apps Development. Procedia - Social and Behavioral Sciences. doi:10.1016/j.sbspro.2012.08.227

Yaman, I. (2015). Digital Divide within the Context of Language and Foreign Language Teaching. Procedia - Social and Behavioral Sciences, 176, 766-771. doi:10.1016/j.sbspro.2015.01.538

Yusof, N. S. M., Hashim, R., \& Rashim, S. N. A. (2012). Assessment of educational divide and computer literacy among primary school students in Selangor Malaysia. In ISBEIA 2012 - IEEE Symposium on Business, Engineering and Industrial Applications (pp. 437-442). doi:10.1109/ISBEIA.2012.6422922

Zhao, L., Lu, Y., Huang, W., \& Wang, Q. (2010). Internet inequality: The relationship between high school students' Internet use in different locations and their Internet self-efficacy. Computers and Education, 55(4), 1405-1423. doi:10.1016/j.compedu.2010.05.010 